\title{
PENINGKATAN PEMBELAJARAN PAI MELALUI DISCOVERY INQUIRY PADA SEKOLAH DASAR DI BANDAR LAMPUNG
}

\author{
Jimi Harianto ${ }^{1}$ Putri Agung ${ }^{2}$ \\ jimiharianto71@yahoo.com \\ Sekolah Tinggi Keguruan Ilmu Pendidikan (STKIP) Al Islam Tunas Bangsa ${ }^{1,2}$
}

\begin{abstract}
In the field, there are many methods of teaching that are not maximally, especially in the study of Islamic education, so that learning is not effective. This study aimed to determine the improvement of Islamic religious education learning through discovery inquiry. This research is a class action research (PTK) or classroom action research, first in developing collaborative teacher work, Teachers are expected to understand the method of learning by Discovery Inquiry approach, So that Islamic religious studies can take place effectively. Secondly, in conducting the approach of discovery inquiry measures and objectives of learning should be clearer and focus so that the efforts to improve Islamic religious learning is well achieved. In this research researchers use the approach of Discovery inquiry guided with a two-way system, which became the subject of action is a class elementary school student V Way Halim Permai Bandar Lampung. In the Act of learning Islamic religion carried out the improvement three times the meeting, except the pre cycle. In cycle I experienced a moderate increase with the average student learning outcomes of $53.34 \%$ or 16 students have not gained increased ability, In cycle II the number of troubled students is $16.67 \%$ or less 5 students. By this it can be concluded that the improvement through the Discovery model of inquiry on the Study of Islamic religious education in class V SDN 2 way Halim Permai Bandar Lampung achieved well so that the learning process results of students experienced improvement.
\end{abstract}

Keywords: Discovery, Inquiry, Learning Islamic Religious Education.

\begin{abstract}
Abstrak
Kenyataan di lapangan banyak dijumpai metode mengajar guru yang belum maksimal khususnya dalam pembelajaran Agama Islam, sehingga dalam proses pembelajaran siswa tidak efektif. Penelitian ini bertujuan untuk mengetahui peningkatan pembelajaran pendidikan agama islam melalui discovery inquiry. Penelitian ini adalah penelitian tindakan kelas (PTK) atau classroom action research, pertama dalam mengembangkan kerja guru yang kolaboratif, sehingga guru diharapkan memahami metode dalam pembelajaran yakni dengan pendekatan discovery inquiry, dan menghasilkan pembelajaran agama islam sesuai dengan kaidah-kaidah pembelajaran yang efektif. Kedua, dalam melaksanakan pendekatan discovery inquiry perlu adanya langkah-langkah dan tujuan pembelajaran yang jelas, sehingga upaya dalam meningkatan pembelajaran agama islam tercapai dengan baik. Selanjutnya penelitian ini menggunakan sistem dua arah yakni menggunakan pendekatan discovery inquiry, yang menjadi subjeknya adalah siswa SD kelas V Way Halim Permai Bandar Lampung. Dalam pelaksanaan tindakan pembelajaran pendidikan agama islam dilakukan perbaikan sebanyak tiga kali pertemuan, kecuali pra siklus. Pada siklus pertama mengalami peningkatan sedang dengan hasil belajar siswa rata-rata $53,34 \%$ atau 16 siswa belum memperoleh peningkatan kemampuan. Pada siklus kedua jumlah siswa yang bermasalah sebanyak 16,67\% atau berkurang 5 siswa. Dengan ini dapat disimpulkan bahwa peningkatan melalui model Discovery inquiry pada pembelajaran Agama Islam di kelas V SDN 2 way halim permai Bandar Lampung tercapai dengan baik sehingga hasil proses belajar siswa mengalami peningkatan yang signifikan.
\end{abstract}

Kata kunci : Peningkatan, Pembelajaran PAI, Discovery, Inquiry 


\section{PENDAHULUAN}

Proses pembelajaran merupakan salah satu masalah yang dihadapi saat ini. Sehingga peran guru penting dalam menunjang keberhasilan suatu pembelajaran dikelas maupun diluar kelas. Maka kegiatan belajar tidak hanya difahami secara hasil, tetapi proses dalam membentuk kepribadian peserta didik agar lebih efektif dalam pembelajaran (Hartinah et al., 2019; Holidun et al., 2018; Komarudin, 2017). Selain itu dibutuhkan inovasi dan kreativitas pembelajaran dalam meningkatkan dan mengembangkan falsafah pendidikan indonesia (Gumanti et al., 2018; Hamidah \& Suherman, 2016). Pembelajaran pendidikan agama islam merupakan upaya guru untuk melaksanakan pembelajaran yang bertujuan untuk memberikan pemahaman, kemampuan, kapasitas siswa dalam bidang ilmu agama islam. Untuk mencapai tujuan tersebut, penting guru untuk memfasilitasi proses pembelajaran menggunakan metode, model dan media yang sesuai tujuan pembelajaran PAI (M. Solichin, 2017), mengehayati dan mengamalkan ajaran ajaran islam seutuhnya (Baidlawi, 2006), sehingga mampu melaksanakan fungsi sebagai khalifah dimuka bumi dalam mewujudkan kebahagian dunia dan akhirat (Nata, 2004), dan strategi yang harus dibentuk pengorganisasian isi bidang studi pendidikan islam merupakan langkah penting (Syah, 2000)

Berbagai model pembelajaran dan pengajaran dalam dunia pendidikan dapat dijadikan kajian menarik untuk di implementasiakan pada kegiatan pembelajaran disekolah, hal ini digunakan untuk mencpai tujuan bagi para perancang pembelajaran (Hamruni, 2011). Pembelajaran yang baik harus mampu menghubungkan antara kegiatan belajar yang dilakukan siswa dengan mengajar yang dilakukan oleh guru. Dalam konteks ini, guru harus dapat mengoptimalkan proses pembelajaran yang ditandai adanya interaksi dan koloborasi antara kegiatan siswa dan guru.

Pola interaksi dan kolaborasi antara siswa dan guru diwujudkan dalam berbagai pendekatan, model dan metode pembelajaran yang memungkinkan tercapainya tujuan pembelajaran, seperti aksplorasi alam, inkuri dan tugas-tugas proyek berbasis masalah. Kegiatan-kegiatan diatas merupakan aktivitas pembelajaran yang hidup dan memberikan kontribusi terhadap pembentukan kepribadian anak secara utuh (Iskandar, 2009), proses tranmisi berbagai ilmu pengetahuan pada setiap individu (Asmuni, 2010). 
Al-Quran menerangkan dalam Surat Al-Baqarah ayat 31. "Dan Dia mengajarkan kepada adam nama-nama (benda-benda) seluruhnya, kemudian mengemukakannya kepada paramalaikat lalu berfirman sebutkan lah kepada-Ku nama-nama benda itu jika memang orang-orang yang benar” (Al-Quran 2:31).

Abd Al-Fatah jalal dalam perspektifnya, menjelskan ta'lim pada ayat diatas menekankan tingginya kedudukan ilmu pengetahuan dalam islam. Ia menegaskan bahwa ta'lim adalah lebih luas dari pada tarbiyah, karena ketika rasulullah SAW mengajarkan bacaan Al Qur'an kepada kaum muslimin, beliau tidak sebatas pada upaya tetapi agar mereka dapat membaca, dan memahami makna ayat tersebut. Lebih dari itu, membaca harus disertai penghayatan dan perenungan yang berisi pemahaman, tanggung jawab,dan amanah yang memungkinkan menerima al-hikmah (M. M. Solichin, 2009).

Desain pembelajaran sangat ditentukan dari ketepatan dalam memilih metode (Andriani et al., 2019; Huda et al., 2019). Langkah yang harus diperhatikan oleh desainer yaitu menetapkan tujuan, karakteristik peserta didik, dan hasil pembelajaran. Sedangkan strategi pengorganisasiannya pada tingkat makro, yaitu strategi yang berkaitan dengan isi kurikulum dan tujuan pendidikan islam.

Salah satu model pembelajaran yang menekankan pada siswa adalah model pembelajaran discovery inquiry. Pembelajaran ini menitikberatkan pada mental intelektual peserta didik dalam menentukan persoalan yang dihadapi, sehingga generalisasi atau konsep yang ditemukan dapat diterapkan dilapangan (Hamalik, 2008). Pengunaan pembelajaran discovery inquiry selain relevan dengan langkah-langkah metodenya, juga relevan dengan teori-teori Piaget, kondisioning dan konstruktif (Nirwana 2013). Selain itu, dalam pembelajaran ini salah satu fokusnya adalah menekankan pada pemecahan masalah, serta model ini kemampuan peserta didik diasah seluruhnya untuk belajar dalam situasi proses berfikir, agar peserta didik dapat meyelesaikan masalah yang dituntut secara mandiri dan percaya diri dan pemecahan masalah dapat teratasi. Sehingga keterlibatan dalam kegiatan logis dan sistematis akan dapat berkembang sesuai dengan arah dan tujuan pembelajaran (Trianto, 2014).

Berbagai penelitian terdahulu telah banyak dilakukan, bahwa metode discovery dapat meningkatkan percaya diri siswa (Muhamad, 2017), dapat meningkatkan hasil belajar (Husain, 2012), menjadikan siswa dapat memecahkan masalah (Handoyono \& 
Arifin, 2016), selain itu dapat meningkatkan kemampuan berpikir kritis dan prestasi belajar dalam ranah pengetahuan, sikap, dan keterampilan (Lastriningsih, 2017). Selain itu terdapat peningkatan proses pembelajaran dengan inquiry (Pujilestari, 2019).

Terdapat perbedaan penelitian terdahulu dengan penelitian ini, bahwa penelitian ini memiliki kebaruan yaitu memadukan 2 buah metode yaitu discovery dan inquiry. Sehingga tujuan penelitian ini adalah untuk mengetahui peningkatan pembelajaran pendidikan agama islam melalui discovery inquiry.

\section{METODE PENELITIAN}

Metode penelitian ini menggunakan Classroom Action Reseach (PTK), yaitu penelitian yang dilaksanakan oleh guru di dalam kelas dengan penekanan pada penyempurnaan praktik dan proses pembelajaran (Susilo et al., 2008). Karakteristik Classroom Action Reseach yaitu:

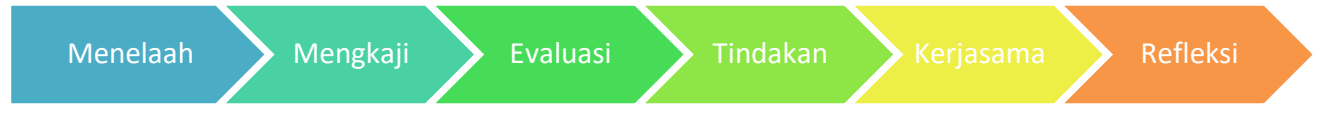

Gambar 1.1. Karakteristik Classroom Action Reseach

Proses penelitian ini terdiri beberapa siklus, setiap siklus dimulai dari perencanaan, pelaksanaan, pengamatan, refleksi, dan evaluasi yang bertujuan untuk mengadakan perbaikan atau peningkatan mutu praktik pembelajaran dikelas dan siklus tersebut adalah:

\section{Gambar 1.2. Siklus Classroom Action Reseach}

Adapun siklus tersebut dilakukan selama 1 minggu yaitu:

1. Perencanaan

Pada tahap perencanaan peneliti melakukan observasi dan wawancara disekolah kemudian merencanakan tindakan yang akan dilakukan dalam menangani kendalakendala permasalahan dikelas V Sekolah Dasar Negeri 2 Way Halim Permai Bandar Lampung dalam kegiatan pembelajaran agama islam dengan menggunakan pendekatan discovery inquiry. 
2. Melaksanakan Tindakan

Ditahap ini peneliti melakukan rencana pelaksanan tindakan kegiatan belajar mengajar dengan menerapkan metode discovery inquiry, seperti yang telah direncanakan sebelumnya didalam pelaksanan pembelajaran. Tindakan ini bersipat terbuka sesuai dengan kejadian dalam proses kegiatan belajar mengajar.

3. Observasi

Dalam melaksanakan observasi peneliti dan kolobolator bekerja sama pada saat kegiatan belajar mengajar dikelas. Kegiatan ini dimaksudkan untuk mengamati proses jalannya kegiatan belajar mengajar di dalam kelas. Dari pengamatan tersebut dapat disimpulkan bahwa kendala yang dialami oleh siswa tentang tinggkat pemahaman dalam pembelajaran agama islam dapat diketahui oleh guru sehingga permasalahan mudah dipecahkan. Selain itu kinerja guru dapat dilakukan dengan pengamatan melalui lembar supervisi yang dilakukan oleh rekan sejawat serta penampilan guru ketika sedang mengajar dikelas dapat terekam secara optimal.

4. Refleksi

Pada tahap ini peneliti dan koloborator meriview kegiatan pembelajaran siswa yang telah dilakukan. Dari hasil observasi tersebut kegiatan yang dilakukan dapat drefleksikan kedalam data observasi sehingga kemampuan siswa dalam menyelesai-kan masalah melalui discoveri inquiry berjalan secara optimal. Hal ini merupakan dasar dalam perbaikan kegiatan-kegiatan yang akan dilaksanakan pada siklus selanjutnya.

Penggunaan discovery inqury dalam penelitian ini memiliki langkah-langkah sebagai berikut (Hanafiah \& Suhana, 2009): 


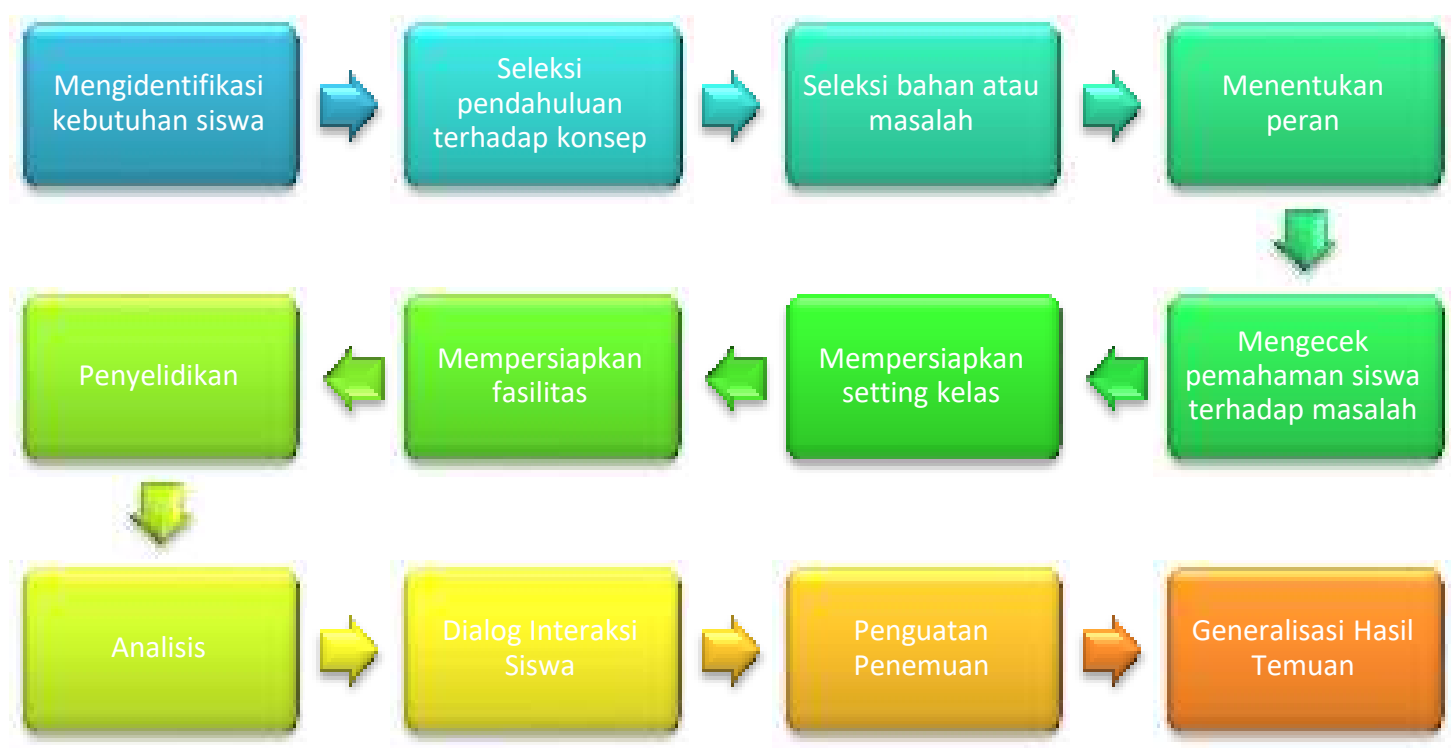

Gambar 1.3. Langkah-Langkah Discovery-Inquiry

Data yang dihasilkan dalam penelitian ini adalah data kuantitatif, yaitu berupa data yang diambil dari pemantauan tindakan dan hasil belajar agama islam dengan mengunakan tes tertulis berbentuk essai. Sedangkan data kualitatif diperoleh dari pengamatan selama proses pembelajaran berlangsung. Sumber data dalam pelaksanan penelitian ini yaitu siswa kelas V SDN 2 Way Halim Permai Bandar Lampung sebagai objek penelitian yang berjumlah 30 siswa yang akan dijadikan penelitian tentang belajar PAI dalam proses pembelajaran dikelas.

\section{HASIL PENELITIAN DAN PEMBAHASAN}

Penelitian tindakan kelas ini bertujuan meningkatkan kemampuan berfikir siswa dalam melaksanakan pembelajaran PAI dengan menggunakan metode bimbingan belajar melalui tiga siklus dan data akan dianalisis. Analisis ini menggunakan metode kualitatif deskriftif. Sedangkan analisis kuantitatifnya mengunakan rumus prosentasi.

Keterangan:

$$
P=\frac{\mathrm{F}}{\mathrm{N}} \times 100
$$

$\mathrm{P}=$ Prosentase Jawaban

$\mathrm{F}=$ Frekuensi Jawaban

$\mathrm{N}=$ Jumlah Responden 


\section{Pra Siklus}

Sebelum pra siklus dilakukan peneliti melakukan observasi secara mendalam dan merefleksi kegiatan pembelajaran. Diketahui hasil ujian siswa kelas V SDN 2 Way Halim Permai dengan materi "Perilaku terpuji", sangat rendah sebabnya antara lain:

a. kurangnya aktif siswa dalam proses pemebelajaran PAI

b. Kurangnya penggunaan metode dalam pembelajaran PAI

c. Belum terpenuhi sarana prasarana disekolah sehingga siswa terhambat dalam memehami pembelajaran PAI.

d. ketika mendapat tugas dari guru siswa tidak menjalankannya dengan baik dan menganggap remeh pelajaran PAI.

\section{Tabel 1.1}

Data nilai ujian PAI siswa kelas V

\begin{tabular}{|c|c|c|c|}
\hline No & Banyaknya siswa & Nilai & Prosentase \\
\hline 1 & 3 & $80-85$ & 10 \\
\hline 2 & 6 & $75-79$ & 20 \\
\hline 3 & 4 & $70-74$ & 13.34 \\
\hline 4 & 4 & $65-69$ & 13.34 \\
\hline 5 & 8 & $60-64$ & 26.67 \\
\hline 6 & 5 & $55-59$ & 16.67 \\
\hline & 30 & Jumlah & 100 \\
\hline
\end{tabular}

Dapat diketahui tabel diatas menunjukan dari 30 siswa kelas V SDN 2 Way Halim Permai pada tahun 2018/2019, 54\% atau sebanyak 16 siswa belum mencapai batas ketuntasan dengan nilai 65 kebawah, sehingga kompetensi dasar belum tercapai sedangkan, yang mendapat nilai 65 ke atas sebanyak 14 siswa atau 46\%. Dalam melaksanakan langkah awal dari identivikasi masalah melalui wawancara kepada 16 siswa diperoleh keterangan sebagai berikut:

1. Hampir semua siswa mengatakan bahwa mereka jarang belajar dirumah. Ada 4 anak yang jarang belajar dirumah, yaitu widya astari, siti zainab, laila maharani, dan farhan syakur

2. Ada lima siswa memberikan alasan pembelajaran PAI kurang menarik dan mengasikan. 
3. enam dari enam belas siswa mengungkapkan setiap pelajaran PAI metodenya ceramah dan tanya jawab. ke enam siswa tersebut syfa azkia, anista rahma, darmawan, rahmat hidayat, zainal arkan dan rudi irawan.

4. Selanjutnya yang menyatakan bahwa pelajaran PAI sangat membosankan adalah tidak digunakannya media yang ada seperti, audio visual serta perpustakaan sekolah.

Maka peneliti dapat menyimpulkan bahwa pelajaran PAI adalah bagaiman guru mendesain pembelajaran menjadi efektif sehingga kesan pelajaran agama islam menarik, mengasyikan dan membangkitkan semangat peserta didik dalam pembelajaran di dalam kelas.

Menurut (Utami, 2013) Langkah-langkah dalam melaksanakan Model pembelajaran Discovery inquiry biasanya menggunakan metode pemberian tugas dan diskusi sebagai proses penetuan problem solvingnya, berikut bentuk pelaksanaan pembelajaran agama islam melalui pendekatan discovery inquiry.

a. Perumusan masalahnya dipecahkan oleh siswa.

Siswa dibagi kedalam kelompok-kelompok kemudian guru memberikan pertanyaan yang merangsang berfikir siswa mengarah pada persiapan pemecahan masalah;

b. Menentukan jawaban sementara atau hipotesis yaitu siswa menetapkan jawaban untuk dikaji lebih lanjut (alternatif jawaban).

c. Siswa mengidentifikasi masalah kemudian mencari informasi, data, dan fakta yang diperlukan untuk menjawab permasalahan. Setiap kelompok mencari, menemukan data dari buku-buku pendidikan agama islam yang relevan, seperti buku LKS dari perpustakaan dan secara spontan siswa menjelajahi informasi untuk menguji data baik secara individu ataupun secara kelompok.

d. Hasil yang diperoleh dari kegiatan dan informasi akan disimpulkan jawabannya oleh siswa.

e. Selanjutnya mengaplikasikan jawaban yang diperoleh setiap kelompok dan dipraktekan didepan kelas. 


\section{Deskripsi data siklus I}

Hasil dari siklus pertama menunjukan beberapa kelemahan dalam bimbingan belajar agama islam bahwa sebanyak 16 siswa atau 53,34\% belum mengalami peningkatan penguasaan, sedangkan 14 atau 46,67\% mengalami peningkatan. Selanjutnya peneliti mengadakan perbaikan tambahan bimbingan belajar dengan menggunakan pendekatan discovery inquiry serta dengan langkah-langkahnya, langkah yang ditempuh memberikan bimbingan terhadap enam belas siswa yang bermasalah dengan penambahan bimbingan belajar setelah jam pulang sekolah, dengan penambahan ini diharapkan siswa akan lebih memahami pelajaran agama islam dan termotivasi mengejar ketinggalan pembelajaran di dalam kelas. Dari kegiatan tambahan bimbingan belajar diperoleh data sebagai berikut:

\section{Tabel 1.2}

Data Tindakan Siklus I

\begin{tabular}{|c|c|c|c|}
\hline No & Frekuensi & Prosentase & Tingkat kreteria \\
\hline 1 & 9 & $53,34 \%$ & Baik \\
\hline 2 & 7 & $46.67 \%$ & Kurang \\
\hline 3 & 16 & 100 & Baik \\
\hline
\end{tabular}

Dari data tambahan bimbingan belajar diketahui ada peningkatan pembelajaran PAI yaitu 9 atau 53,34\% siswa sudah mengalami peningkatan, Sedangkan 7 atau 46,67\% siswa belum ada peningkatan.

Data sebelum siklus I dan sesudah dilaksanakan tambahan bimbingan dapat dilihat pada tabel dibawah ini:

Tabel 1.3

Data Sesudah Bimbingan Siklus I

\begin{tabular}{|c|c|c|c|}
\hline Tindakan & Tingkat Kriteria & F & P \\
\hline Sebelum siklus I & Tinggi & 16 & $53,34 \%$ \\
& Rendah & 14 & $46,67 \%$ \\
\hline Jumlah & & 30 & $100 \%$ \\
\hline Setelah siklus I & Tinggi & 23 & $76,67 \%$ \\
& Rendah & 7 & $23,34 \%$ \\
\hline Jumlah & & 30 & $100 \%$ \\
\hline
\end{tabular}

Dari pemberian bimbingan belajar tambahan dapat diperoleh informasi bahwa pendekatan dengan menggunakan discovery inquiry dapat meningkatkan pembelajaran agama islam dengan berkurangnya siswa dari 16 atau 53,34\% siswa bermasalah berkurang menjadi 7 atau 23,34\% siswa. Hasil tindakan siklus 
1 ini akan dijadikan evaluasi karena, siklus 1 ini belum mencapai tingkat signifikan maka akan digunakan tindakan siklus berikutnya.

\section{Deskripsi data siklus II}

Pelaksanaan tindakan siklus II ini terdapat kelemahan yang harus diperbaiki dalam bimbingan belajar. Dari hasil wawancara siklus II masih terdapat 7 atau 23,34\% siswa yang masih memerlukan bimbingan. Oleh karena itu untuk melanjutkan keberhasilan bimbingan belajar pada siklus II, peneliti mengadakan wawancara kepada 7 siswa yang bermasalah, peneliti mendapatkan jawaban sebagai berikut:

a. Ahmad Zaki dan Rahmat Hidayat masih butuh bimbingan, karena belum sepenuhnya memahami langkah-langkah discovery inquiry, dan mereka masih menganggap sulit.

b. Lima dari enam belas siswa yang bermasalah selanjutnya akan diberikan metode discovery inquiry dalam bimbingan belajar tambahan.

c. Syfa Azkia, Rangga Saputra, Darmawan, Laila Maharani, Anistia Rahma, Siti zainab dan Widya Astari keseluruhan memahami materi dan langkahlangkahnya.

d. Sedangkan Bagus Jayadi, Rudi Irawan, dan Raihan Anggara mulai ada kemajuan dan masih butuh bimbingan, meskipun bimbingan belajar sudah banyak diikuti.

e. Secara keseluruhan, lima dari enem belas siswa yang bermasalah akan diberikan tindakan siklus berikutnya.

Pada tindakan siklus II dapat diketahui yang mengalami peningkatan pembelajaran agama islam melalui pendekatan discovery inquiry dapat dilihat pada tabel di bawah ini.

Tabel 1.4

Data Setelah Bimbingan Siklus II

\begin{tabular}{|l|c|c|c|}
\hline Tindakan & Tingkat Kriteria & Frekuensi & Prosentase \\
\hline Siklus I & Tinggi & 23 & $76,67 \%$ \\
& Rendah & 7 & $23,34 \%$ \\
\hline Jumlah & & 30 & $100 \%$ \\
\hline Siklus & Tinggi & 28 & $93,34 \%$ \\
II & Rendah & 2 & $6,67 \%$ \\
\hline Jumlah & & 30 & $100 \%$ \\
\hline
\end{tabular}


Dapat disimpulkan bahwa pasca tindakan siklus II jumlah siswa yang bermasalah berkurang 5 siswa atau 16,67\%, Maka dalam hal ini masih terdapat 2 siswa atau $6,67 \%$ yang belum mengalami perubahan, dari 2 siswa tersebut maka bimbingan belajar masih akan dilakukan dalam tahap perbaikan pada tindakan siklus ke tiga, sehingga dari 16 siswa yang bermasalah dalam upaya meningkatkan pembelajaran PAI melalui pendekatan discovery inquiry akan dapat teratasi semua setelah tindakan bimbingan belajar yang diberikan.

\section{Deskripsi siklus III}

Pada tindakan siklus II setelah melakukan evaluasi serta perbaikan-perbaikan maka, dalam siklus III ini dapat dikatankan berhasil dalam mengatasi permasalahan. Dari siklus III ini diperoleh data sebagai berikut:

Tabel 1.5

Data Tindakan Siklus III

\begin{tabular}{|c|c|c|c|}
\hline No & Frekuensi & Prosentase & Tingkat kreteria \\
\hline 1 & 16 & 100 & Baik \\
\hline 2 & 0 & 0 & Kurang \\
\hline 3 & 16 & 100 & Baik \\
\hline
\end{tabular}

dari tabel diatas, dapat disimpulkan bahwa:

a. Berdasarkan pengulangan materi pada siklus III, 2 siswa atau $6,67 \%$ siswa bermasalah dapat teratasi, hal ini dapat dilihat kedua anak tersebut melaksanakan tugasnya sesuai dengan langkah-langkah yang telah diajarkan.

b. Dalam pembelajaran PAI kedua siswa yang bermasalah sudah memhami materi tentang prilaku terpuji.

c. Secara keseluruhan, dari enam belas siswa sudah memahami proses pembelajaran serta langkah-langkah discovery inquiry.

Kemudian siklus III ini peneliti melakukan wawancara dan hasil tersebut adalah:

1) Dengan adanya tambahan bimbingan belajar PAI yang berkelanjutan, maka pembelajaran melalui pendakatan discovery inquiry tercapai tuntas.

2) Bimbingan belajar yang sudah mereka lakukan mempunyai pengaruh besar dalam rangka peningkatan pembelajaran agama islam disekolah. 
Hasil bimbingan belajar dari siklus I, II dan III dapat disimpulkan bahwa pembelajaran agama islam melalui pendekatan discoveri inquiry di SDN 2 Way Halim Permai behasil 100\%. Dari 16 siswa yang bermasalah mulai beradaptasi dengan siswa lainnya. Mereka menganggap penggunaan pendekatan discovery inquiry pada mata pelajaran PAI memberikan solusi, sehingga siswa cenderung aktif dalam proses pembelajaran yang berlangsung baik di dalam maupun di luar kelas.

Hasil dari analisis ini dapat diketahui pada tabel di bawah ini:

Tabel 1.6

Data Bimbingan Siklus III

\begin{tabular}{|c|c|c|c|}
\hline Tindakan & Tingkat kreteria & Frekwensi & Prosentase \\
\hline Siklus I & Tinggi & 23 & $76,67 \%$ \\
\hline Jumlah & & 30 & $100 \%$ \\
\hline Siklus II & Tinggi & 28 & $93,34 \%$ \\
\hline Jumlah & & 30 & $100 \%$ \\
\hline Siklus III & Tinggi & 30 & $100 \%$ \\
\hline Jumlah & & 30 & $100 \%$ \\
\hline
\end{tabular}

Dari tabel diatas dapat simpulkan siswa yang mengikuti bimbingan belajar siklus I, II dan III mengalami peningkatan secara bertahap, dengan adanya tindakan tersebut siswa lebih aktif serta tugas yang diberikan oleh guru dikerjakan dan dilaksanakan penuh tanggung jawab.

Secara keseluruhan siklus tindakan kelas dapat digambarkan sebagai berikut:

1. Pra Tindakan siklus I

Jumlah siswa sebanyak 30 yang akan dijadikan subjek penelitian terdapat 16 siswa yang bermasalah.

2. Tindakan Siklus I

Setelah melaksanakan tindakan siklus pertama, 9 siswa mengalami peningkatan, tetapi 7 siswa lainya belum mengalami peningkatan yang signifikan. Maka akan diberikan tambahan bimbingan belajar selanjutnya.

3. Tindakan Siklus II

Setelah mengikuti tambahan bimbingan belajar pada siklus kedua, 7 siswa yang mengikuti bimbingan diantarannya 5 siswa mengalami kemajuan dan masih ada 2 siswa lainya perlu mendapat bimbingan khusus pada siklus III. 


\section{Tindakan Siklus III}

Setelah dilaksanakan bimbingan belajar siklus yang kedua mereka yang belum mengalami kemajuan dan peningkatan akan dilanjutkan kesiklus yang ketiga. Pada awalnya masih terdapat 2 siswa yang masih perlu mendapatkan bimbingan belajar sekarang semua sudah teratasi setelah mendapatkan bimbingan belajar pada siklus ketiga.

Dari tindakan siklus I, II, dan III dapat disimpulkan dengan tambahan bimbingan belajar melalui pendekatan discovery inquiri pembelajaran PAI teratasi dengan baik. Hal ini dapat di buktikan dari 16 siswa yang mengalami kesulitan belajar sudah dapat beradaptasi dengan teman dikelasnya.

\section{SIMPULAN DAN SARAN}

Terdapat peningkatan setiap siklus, siklus pertama mengalami peningkatan sedang dengan hasil belajar siswa rata-rata 53,34\% atau 16 siswa belum memperoleh peningkatan kemampuan. Pada siklus kedua jumlah siswa yang bermasalah sebanyak $16,67 \%$ atau berkurang 5 siswa. Dengan ini dapat disimpulkan bahwa peningkatan melalui model discovery inquiry pada pembelajaran Agama Islam di kelas V SDN 2 way halim permai Bandar Lampung tercapai dengan baik sehingga hasil proses belajar siswa mengalami peningkatan yang signifikan.

Pembelajaran PAI pada tingkat SD khususnya di SDN 2 Way Halim Permai Bandar Lampung belum sepenuhnya mengacu pada pendekatan pembelajaran yang berpusat pada peserta didik (student center learn), faktornya adalah: kurang aktif siswa dalam proses pembelajaran, metode yang dugunakan hanya ceramah dan tanya jawab, terbatasnya sarana dan prasarana di sekolah yang mengakibatkan kemampuan yang diperoleh para peserta didik tidak tuntas secara komprehensif. Selanjutnya Langkah yang digunakan untuk meningkatkan pembelajaran PAI adalah memperjelas tujuan belajar agar guru selalu menekankan murid menggunakan pendekatan discoveri inquiri walaupun setiap pendekatan pasti ada kekurangan dan kelebihannya, memberikan materi dengan metode yang bervariasi, membiasakan maju kedepan kelas dan menjelaskan langkah-langkah discovery inquiri dalam materi pembelajaran. 


\section{DAFTAR PUSTAKA}

Andriani, S., Suyitno, H., \& Junaidi, I. (2019). The Application of Differential Equation of Verhulst Population Model on Estimation of Bandar Lampung Population. Journal of Physics: Conference Series, 1155, 012017.

Asmuni, A. (2010). Fikih Kontemporer. Duta Azhar.

Baidlawi, H. M. (2006). Modernisasi Pendidikan Islam (Telaah Atas Pembaharuan Pendidikan di Pesantren). TADRIS: Jurnal Pendidikan Islam, 1(2).

Gumanti, A. A. M., Supriadi, N., \& Suherman, S. (2018). Pengaruh Pembelajaran dengan Musik Klasik Terhadap Kemampuan Pemecahan Masalah Matematis Peserta Didik. Prosiding Seminar Nasional Matematika Dan Pendidikan Matematika, 1, 393-399.

Hamalik, O. (2008). Proses belajar mengajar. Rev. Ed. Jakarta: Bumi Aksara.

Hamidah, K., \& Suherman, S. (2016). Proses Berpikir Matematis Siswa dalam Menyelesaikan Masalah Matematika di tinjau dari Tipe Kepribadian Keirsey. AlJabar: Jurnal Pendidikan Matematika, 7(2), 231-248.

Hamruni, A. (2011). Strategi Pembelajaran. Yogyakarta: Insan Madani.

Hanafiah, N., \& Suhana, C. (2009). Konsep strategi pembelajaran. Bandung: Refika Aditama.

Handoyono, N. A., \& Arifin, Z. (2016). Pengaruh inquiry learning dan problem-based learning terhadap hasil belajar PKKR ditinjau dari motivasi belajar. Jurnal Pendidikan Vokasi, 6(1), 31-42.

Hartinah, S., Suherman, S., Syazali, M., Efendi, H., Junaidi, R., Jermsittiparsert, K., \& Umam, R. (2019). Probing-Prompting Based On Ethnomathematics Learning Model: The Effect On Mathematical Communication Skill. Journal for the Education of Gifted Young Scientists, 7(4), 799-814.

Holidun, H., Masykur, R., Suherman, S., \& Putra, F. G. (2018). Kemampuan Pemecahan Masalah Matematis Kelompok Matematika Ilmu Alam dan IlmuIlmu Sosial. Desimal: Jurnal Matematika, 1(1), 29-37.

Huda, S., Rinaldi, A., Suherman, S., Sugiharta, I., Astuti, D. W., Fatimah, O., \& Prasetiyo, A. E. (2019). Understanding of Mathematical Concepts in the Linear Equation with Two Variables: Impact of E-Learning and Blended Learning Using Google Classroom. Al-Jabar: Jurnal Pendidikan Matematika, 10(2), 261270.

Husain, R. T. (2012). Penerapan Metode Discovery Learning dalam Meningkatkan Hasil Belajar Siswa pada Mata Pelajaran Quree an Hadits di MTs Kiayi Modjo Kecamatan Limboto Barat. Gorontalo: Jurusan Pendidikan Agama Islam IAIN Sultan Amai Gorontalo. 
Iskandar, M. (2009). Psikologi Pendidikan Sebuah Orientasi Baru. Ciputat: Gaung Persada Press.

Komarudin, K. (2017). Analisis kesalahan siswa dalam pemecahan masalah matematika pada materi peluang berdasarkan high order thinking dan pemberian scaffolding. Jurnal Darussalam: Jurnal Pendidikan, Komunikasi Dan Pemikiran Hukum Islam, 8(1), 202-217.

Lastriningsih, L. (2017). Peningkatan berpikir kritis dan prestasi belajar melalui metode inquiry pada siswa kelas IV SD. Jurnal Prima Edukasia, 5(1), 68-78.

Muhamad, N. (2017). Pengaruh Metode Discovery Learning untuk Meningkatkan Representasi Matematis dan Percaya Diri Siswa. Jurnal Pendidikan UNIGA, 10(1), 9-22.

Nata, A. (2004). Sejarah Pendidikan Islam: Pada Periode Klasik dan Pertengahan. Rajagrafindo.

NIRWANA, N. (2013). Penggunaan Model Inquiry Berbasis Ict Untuk Meningkatkan Hasil Belajar Pada Mata Kuliah Sejarah Fisika Mahasiswa Prodi Pendidikan Fisika Jurusan Pendidikan Mipa Fkip Univeristas Bengkulu. Prosiding SEMIRATA 2013, 1(1).

Pujilestari, P. (2019). MENINGKATKAN KEMAMPUAN PEMECAHAN MASALAH SEGIEMPAT MELALUI METODE INQUIRY PADA SISWA SMP NEGERI 19 MATARAM. JISIP: Jurnal Ilmu Sosial Dan Pendidikan, 1(2).

Solichin, M. (2017). Penerapan Model Pembelajaran Inquiry Discovery dalam Pendidikan Agama Islam. TADRIS: Jurnal Pendidikan Islam, 12(2), 214-231.

Solichin, M. M. (2009). Tazkiyah al-Nafs sebagai Ruh Rekonstruksi Sistem Pendidikan Islam. TADRIS: Jurnal Pendidikan Islam, 4(1).

Suherman, S. (2015). Kreativitas Siswa Dalam Memecahkan Masalah Matematika Materi Pola Bilangan Dengan Pendekatan Matematika Realistik (PMR). AlJabar: Jurnal Pendidikan Matematika, 6(1), 81-90.

Susilo, H., Chotimah, H., \& Sari, Y. D. (2008). Penelitian Tindakan Kelas Sebagai Sarana Pengembangan Keprofesionalan Guru dan Calon Guru. Malang: Bayumedia Publishing.

Syah, M. (2000). Psikologi pendidikan pendekatan baru. Bandung: Remaja Rosdakarya.

Trianto, I. B. A. (2014). Mendesain model pembelajaran inovatif, progresif, dan kontekstual. Jakarta: Prenadamedia Group.

Utami, S. (2013). Peningkatan Minat Belajar Murid Pada Pembelajaran Matematika Dengan Menggunakan Mentode Inquiri Di Sekolah Dasar. Jurnal Pendidikan Dan Pembelajaran, 2(4). 